
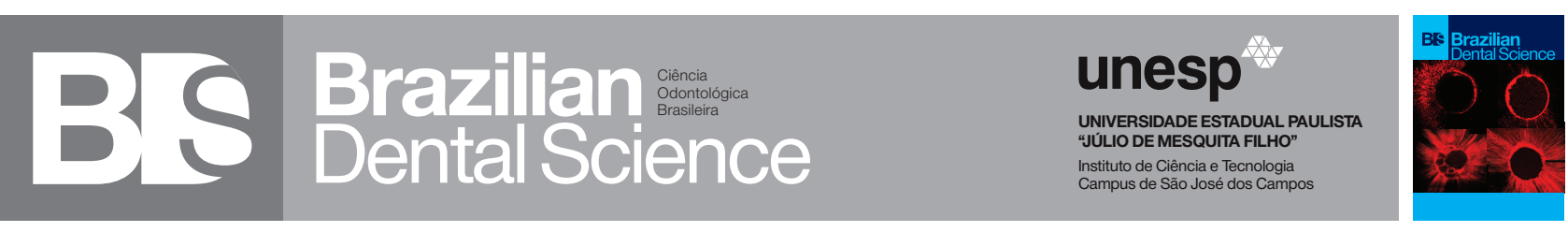

\title{
Influence of the addition of glass fibers reinforcements in the flexural strength of acrylic resin
}

Influência da adição de reforço de fibra de vidro na resistência flexural de resina acrílica

João Gabriel Ezequiel POSSARI ${ }^{1}$, Samia Cristina Mota SACORAGUE ${ }^{1}$, Fernanda Alves FEITOSA ${ }^{2}$, Marcela Moreira PENTEADO ${ }^{1}$, Luigi Giovanni Bernardo SICHI ${ }^{1}$, Rodrigo Máximo de ARAÚJO ${ }^{1}$

1 - Unesp - Univ Estadual Paulista - Institute of Science and Tecnologia, São José dos Campos - Department of Dental Materials and Prosthodontics - São José dos Campos - SP - Brazil.

2 - São Lucas College - Department of Odontology - Caçapava - SP - Brazil.

\section{ABSTRACT}

Objective: To evaluate the influence of glass fiber reinforcements used in nautical and sports products on the flexural strength of acrylic resin. Materials and methods: Thirty thermoactivated acrylic resin bars (25 x $10.5 \mathrm{x}$ $3.3 \mathrm{~mm}$ ) were used. The samples were shared in 3 groups: bars with no glass fiber (control group, $\mathrm{n}=10$ ), bars reinforced with glass fiber and $0.18 \mathrm{~mm}$ thickness (group $\mathrm{F} 1, \mathrm{n}=10$ ) and bars reinforced with glass fiber and 0.80 mm thickness (group F2, $\mathrm{n}=10$ ). After 48 hours, samples were submitted to compression test in order to evaluate flexural strength. Obtained data were statistically analyzed with significance level of $5 \%$. Results: It was observed that the use of glass fiber effectively increased the flexural strength compared to the control group; the thickness of the glass fiber, however, did not present statistical differences. Conclusion: The use of fiber glass is a simple and cost-effective alternative to improve acrylic resin performance.

\section{KEYWORDS}

Flexural strength; Water sports; Dentures.

\section{RESUMO}

Objetivo: Avaliar a influência do reforço de fibra de vidro usada em produtos esportivos náuticos na resistência flexural da resina acrílica. Materias e métodos: Trinta barras de resina acrílica termoativadas ( $25 \times 10.5 \times 3.3 \mathrm{~mm})$ foram confeccionadas. As amostras foram divididas em 3 grupos: barras sem fibra de vidro (grupo controle, $\mathrm{n}=10$ ), barras com reforço de fibra de vidro com espessura de $0.18 \mathrm{~mm}$ (grupo $\mathrm{F} 1, \mathrm{n}=10$ ) e barras com reforço de fibra de vidro com espessura de 0.80 $\mathrm{mm}$ (grupo F2, $\mathrm{n}=10$ ). Após 48 horas, as amostras foram submetidas ao ensaio de compressão para avaliar a resistência flexural. Os dados obtidos foram analisados estatisticamente com nível de significância de 5\%. Resultados: Foi observado que o uso de fibra de vidro aumentou efetivamente a resistência à compressão comparado com o grupo controle; a espessura da fibra de vidro, no entanto, não apresentou diferença estatisticamente significante. Conclusão: $\mathrm{O}$ uso de fibra de vidro é uma alternative simples e de baixo custo para aprimorar a performance das resinas acrílicas.

\section{PALAVRAS-CHAVE}

Resistência flexural; Esportes aquáticos; Dentaduras. 


\section{INTRODUCTION}

$\mathrm{T}$ he use of full prostheses often elicits wearing due to the masticatory process and the form of hygiene. Some patients despite losing their natural teeth, remain with great masticatory force, which is often responsible for prostheses fracturing. Furthermore, accidents falls during handling may also happen, culminating in fractures.

Aiming at solving these questions, reinforcements in the bases of full prostheses were proposed to increase the strength of the acrylic resin [1]. Metal [2], carbon fiber and glass fiber have already been used for this purpose; however, glass fibers present enhanced biocompatibility, rigidness, are more aesthetic, and absorb less water [1]. Additionally, it presents a considerable increase in the support of the flexural [3], transverse and diametrical [4,5] forces that can occur when the prosthesis is in function, thereby increasingly motivating its use [6].

Glass fibers are used in several applications such as in storage (water tanks and swi mming pools) and automobile industry, as they have favorable mechanical properties when subjected to stress, as well as resistance to heat, moisture and corrosion, in addition to simple manufacturing and low cost [7].

In the case of nautical materials, glass fibers are marketed with different thicknesses and wefts [8] and are inexpensive compared to the traditional glass fibers used in Dentistry. In this sense, the purpose of this research is to evaluate the mechanical behavior of acrylic resin bars with and without glass fibers that are co mmonly found to reinforce nautical and sports materials that receive high impact. The null hypothesis is that there is no increase in flexural strength of reinforced bars with these types of fibers.

\section{MATERIAL AND METHODS}

To evaluate the flexural strength in acrylic resin, 30 bars were produced from a metallic die in the dimensions of $25 \times 10.5 \times$ $3.3 \mathrm{~mm}$ (Figure 1), which were divided into 3 groups of 10 samples: a control group of acrylic resin (Classical - Thermo-polymerizing acrylic), the F1 group were 10 samples with bidirectional glass fiber with a thickness of $0.18 \mathrm{~mm}$ (Fibertex) associated with the acrylic resin and group F2 with 10 samples of glass fiber with a thickness of $0.80 \mathrm{~mm}$ (Fibertex) associated with the acrylic resin (Figure 2). Fibers were acco mmodated between two layers of acrylic resin and submitted to muffle to thermo-polymerizing (Figure 3). After 48 hours the samples were submitted to the threepoint bending test in a universal test machine EMIC (Model DL-1000, EMIC Equipamentos e Sistemas LTDA., São José dos Pinhais - PR Brazil), under the following parameters: load of $100 \mathrm{Kgf}$, velocity of $1 \mathrm{~mm} / \mathrm{min}$ at the center of samples. Obtained data were statistically analyzed with a significance level of 95\%, using one-way ANOVA and Tukey test to show statistical significant difference $(\mathrm{p}<0.05)$.

To evaluate the flexural strength in acrylic resin, 30 bars were produced from a metallic die in the dimensions of $25 \times 10.5 \times$ $3.3 \mathrm{~mm}$ (Figure 1), which were divided into 3 groups of 10 samples: a control group of acrylic resin (Classical - Thermo-polymerizing acrylic), the $\mathrm{F} 1$ group were 10 samples with bidirectional glass fiber with a thickness of $0.18 \mathrm{~mm}$ (Fibertex) associated with the acrylic resin and group F2 with 10 samples of glass fiber with a thickness of $0.80 \mathrm{~mm}$ (Fibertex) associated with the acrylic resin (Figure 2). Fibers were acco mmodated between two layers of acrylic resin and submitted to muffle to thermo-polymerizing (Figure 3). After 48 hours the samples were submitted to the threepoint bending test in a universal test machine EMIC (Model DL-1000, EMIC Equipamentos e Sistemas LTDA., São José dos Pinhais - PR Brazil), under the following parameters: load 
of $100 \mathrm{Kgf}$, velocity of $1 \mathrm{~mm} / \mathrm{min}$ at the center of samples. Obtained data were statistically analyzed with a significance level of $95 \%$, using one-way ANOVA and Tukey test to show statistical significant difference $(p<0.05)$.
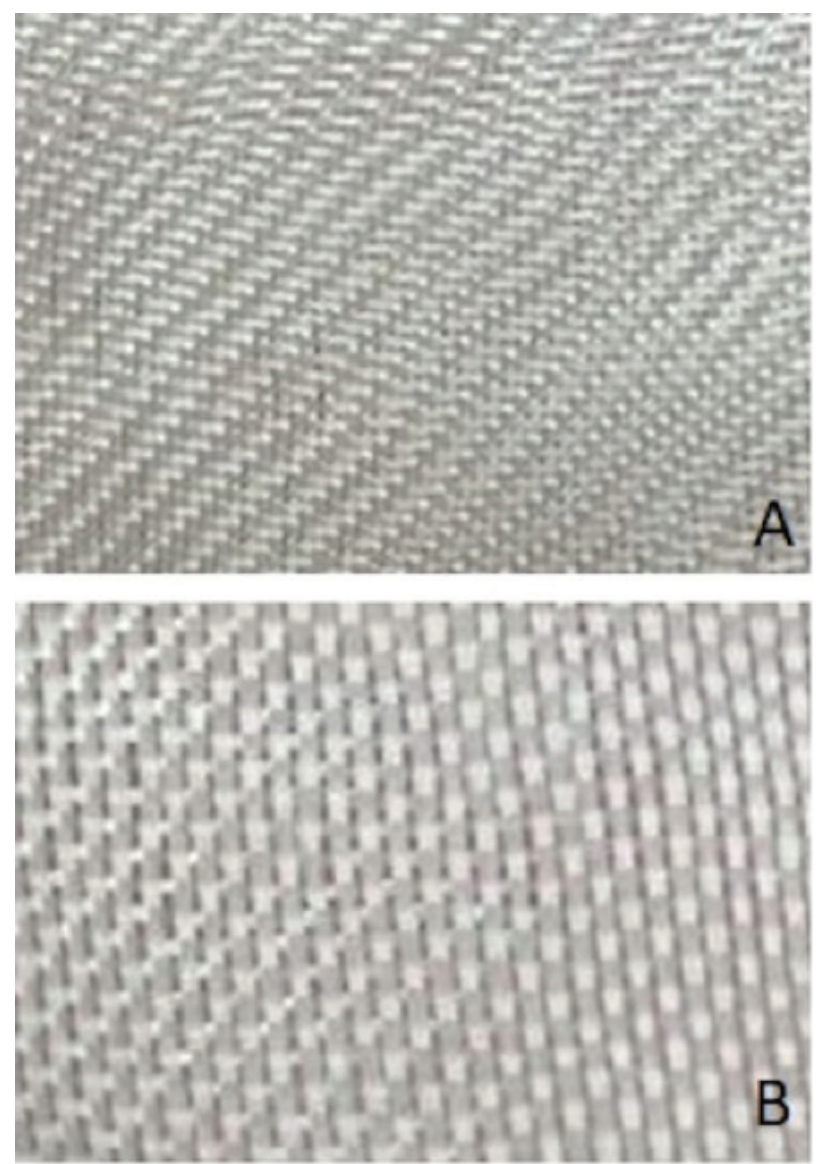

Figure 1 - A. Fiber glass with weft of 5 wires and thickness of $0.18 \mathrm{~mm}$. B. Fiber glass with weft of $1.7 \mathrm{~mm}$ and thickness of $0.80 \mathrm{~mm}$.
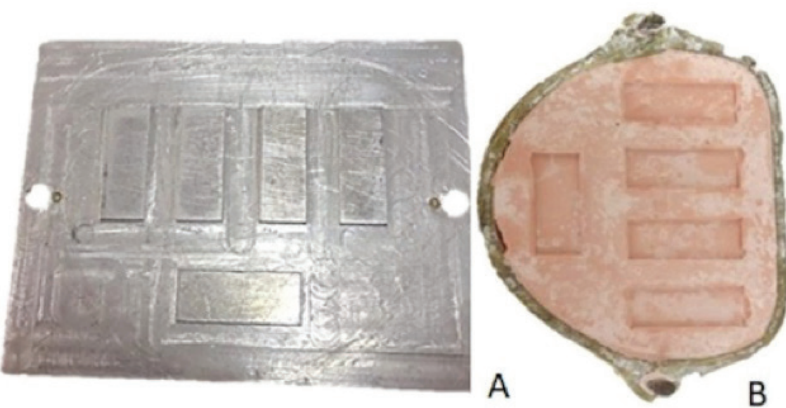

Figure 2 - Bars with glass fiber, cut lengthwise prior to mechanical testing. A. Control Group. B. Group F1. C. Group F2.

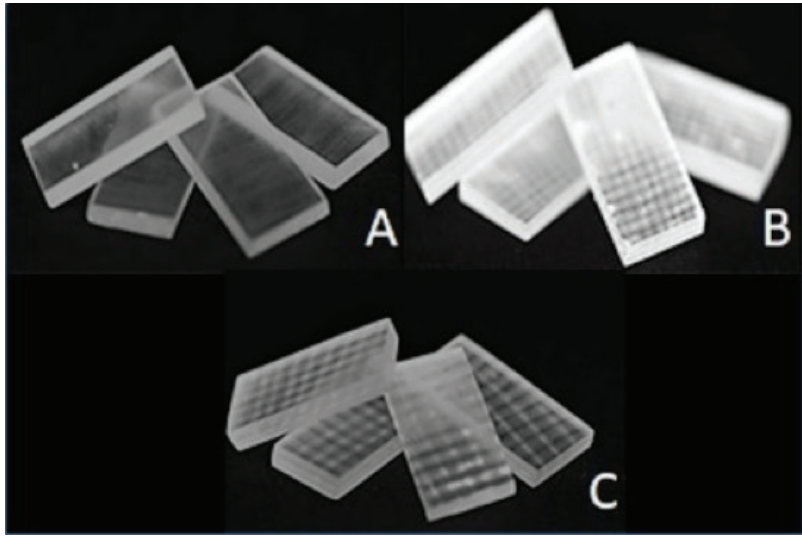

Figure 3 - A. Stainless steel metallic pattern with the dimensions of the bars. B. Muffle filled with plaster IV containing niches to the produce de bars.

\section{RESULTS}

Figure 4 demonstrates the results of mean and standard deviation with letters representing the Tukey test results. It is possible to infer that the use of glass fiber increased the flexural strength compared with the control group, but the thickness of the glass fiber presented no statistical differences.

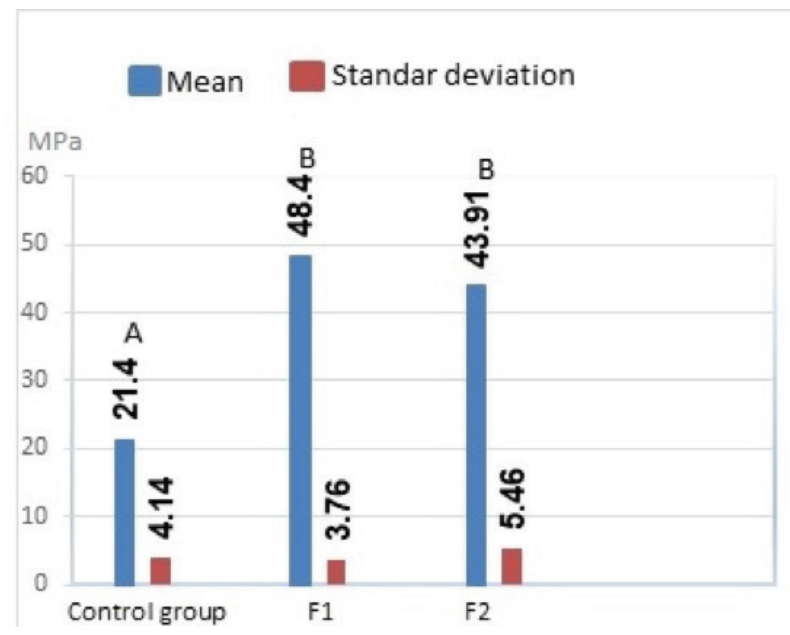

Figure 4 - Mean and standard deviation values of flexural strength. Different letters represent significant statistical differences, while equal letters represent no significance. 


\section{DISCUSSION}

Considering the results, the null hypothesis was rejected as the two groups that received fibers (F1 and F2) presented higher flexural strength means.

These findings corroborate with contributions from Uzun et al. [9], Murthy et al.[2] and Li et al. [10], which observed that reinforcement with fibers in the form of tissue or particles incorporated into the acrylic resin responded favorably to increase the strength of the full denture bases that were tested.

During the flexural strength test, it was found cracks or catastrophic failures started at tensile side [11]. The acrylic resin is able to deform before fracturing, but the glass fiber absorbed more tension by stretching and the initial failure occurred of highest stress [12]. Besides that, the groups with fiber glass reinforcements do not detached from the system after the fracture, which may prevent intra-oral accidents.

Interesting results by finite elements analysis were found also to an-implant supported overdentures [13]. The fiber glass reinforcements improved load distribution and minimized the risk of denture base fracture. Thus the alternative to use fiber glass reinforcements can be use to differences kinds of prosthetic treatments.

The main advantage of sport-related glass fibers is the diversity of specifications available in the market. Raw materials can be purchased in the form of a blanket, with costs associated with the requested number of meters. Object geometry is an important aspect of fracture behavior [14]. Large objects require large amounts of continuous fibers for best performance [14]. In the case of full dentures however, centimeters are sufficient, which considerably decreases the cost.

Moreover, the ease of acquiring blankets in meters favors uniform application without patches and consequently the performance of the product when subjected to tension is enhanced.
It is a lightweight material made to receive high impact, so that sports materials and accessories do not easily fracture or injure the athlete.

Cost is reduced in comparison with fibers traditionally used in Dentistry and because it is surrounded by an acrylic resin, it shows no biocompatibility issues. In cases of damages, the material may be fixed or restored, which in terms of Dentistry involves less associated costs when compared with the production of a new dental prosthesis.

\section{CONCLUSION}

Glass fibers used in nautical and sports materials with high impact increased the flexural strength of acrylic resin bars, regardless of their thickness. Thus, we hereby suggest that it may be a promising alternative material for clinical use, with good cost-effectiveness.

\section{REFERENCES}

1. Gad MM, Fouda SM, Al-Harbi FA, Näpänkangas R, Raustia A. PMMA denture base material enhancement: a review of fiber, filler, and nanofiller addition. Int J Nanomedicine. 2017;12:3801-12. Published 2017 May 17. doi: 10.2147/IJN.S130722.

2. Murthy HB, Shaik S, Sachdeva H, Khare S, Haralur SB, Roopa KT. Effect of reinforcement using stainless steel mesh, glass fibers, and polyethylene on the impact strength of heat cure denture base resin - an in vitro study. $\mathrm{J}$ Int Oral Health. 2015;7(6):71-9.

3. Uctasli MB, Arisu HD, Lasilla LV, Valittu PK. Effect of preheating on the mechanical properties of resin composites. Eur J Dent. 2008;2(4):263-8.

4. Monaco C, Arena A, Scotti R, Krejci I. Fracture strength of endodontically treated teeth restored with composite overlays with and without glassfiber reinforcement. J Adhes Dent. 2016;18(2):143-9. doi:10.3290/j.jad. a35908.

5. Fonseca RB, de Almeida LN, Mendes GA, Kasuya AV, Favarão IN, de Paula MS. Effect of short glass fiber/filler particle proportion on flexural and diametral tensile strength of a novel fiber-reinforced composite. $\mathrm{J}$ Prosthodont Res. 2016;60(1):47-53. doi:101016/j.jpor.2015.10.004.

6. Jeganathan S, Lin CC. Denture stomatitis--a review of the aetiology, diagnosis and management. Aust Dent J. 1992;37(2):107-14. doi:10.1111/j.1834-7819.1992.tb03046.x.

7. Wambua P, Ivens J, Verpoest I. Natural fibres: can they replace glass in fibre reinforced plastics? Compos Sci Technol. 2003 Jul;63(9):1259-64. doi: 10.1016/S0266-3538(03)00096-4

8. Ansell MP. Natural fibre composites in a marine environment. Materials, processes and applications 2014;365-74. doi: https://doi.org/10.1533/978 0857099228.3.365.

9. Uzun G, Hersek N, Tinçer T. Effect of five woven fiber reinforcements on 
the impact and transverse strength of a denture base resin. J Prosthet Dent. 1999;81(5):616-20. doi:10.1016/s0022-3913(99)70218-0.

10. Li BB, Xu JB, Cui HY, Lin Y, Di P. In vitro evaluation of the flexural properties of All-on-Four provisional fixed denture base resin partially reinforced with fibers. Dent Mater J. 2016;35(2):264-9. doi:10.4012/dmj.2015-243.

11. Goguță LM, Bratu D, Jivănescu A, Erimescu R, Mărcăuțeanu C. Glass fibre reinforced acrylic resin complete dentures: a 5 -year clinical study. Gerodontology. 2012;29(1):64-9. doi:10.1111//.1741-2358.2010.00385.x.
12 Miranda JS, Marinho CC, Macedo VC, Barcellos ASP, Paradella TC, Paes Jr TJA, et al. Influence of indirect reinforcements on the flexural strength of a thermally activated acrylic resin used for complete dentures. Braz Dent Sci 2018;21(2):150-6. doi: 10.14295/bds.2018.v21i2.

13. Berger G, Pereira LFO, Souza EM, Rached RN. A 3D finite element analysis of glass fiber reinforcement designs on the stress of an implant-supported overdenture. J Prosthet Dent. 2019;121(5):865.e1-865.e7. doi: 10.1016/j. prosdent.2019.02.010.

14. Mattheus FL, Rawlings RD. Composite materials: engeneering and science. Cambridge: Woodhead Publishing Limited, Champman \& Hall; 2008.

\section{Marcela Moreira Penteado}

(Corresponding address)

Department of Dental Materials and Prosthodontics

R. Eng. Francisco José Longo, 777 São Dimas 12245-000

São José dos Campos/SP - Brazil

Date submitted: 2019 Dec 16

E-mail: dramarcelamoreira@hotmail.com

Accept submission: 2020 Mar 10 